Ткачук П. С. Ворона T.O².

${ }^{1}$ - Національна академія Державної прикордонної служби України імені Богдана Хмельницького, Хмельницький;

2 - Центр воєнно-стратегічних досліджень Національного університету оборони України імені Івана Черняховського, Київ

\title{
Підходи до побудови концепції екологічного моніторингу операційних зон регіонального збройного конфлікту при ведені службово-бойової діяльності прикордонних підрозділів на ділянці регіонального управління
}

Резюме. В статті наведено основні підходи для побудови концепції екологічного моніторингу при ведені службово-бойової діяльності прикордонних підрозділів на ділянці регіонального управління з точки зору формування його функціональної схеми та складових для оцінки змін стану прикордонних природнотехногенних геосистем.

Ключові слова: екологічний моніторинг, концепція, природно-техногенна геосистема, воєннотехногенне навантаження, збройний конфлікт, навколишнє середовище, прикордонні райони, службовобойова діяльність, прикордонний підрозділ, індикатори, регіональне управління.

Постановка проблеми. Збройний конфлікт, який розгорнувся на південному сході України, призвів до загибелі тисяч людей і зростання екологічної та гуманітарної катастрофи в Донецько-Луганському регіоні. Це, в свою чергу, впливає на функціонування Державної прикордонної служби України (далі - ДПСУ) щодо організації оперативнослужбової та службово-бойової діяльності, моніторингу цього прикордонного регіону для захисту національних інтересів від зовнішніх та внутрішніх мультисистемних загроз.

Відповіддю з боку ДПСУ повинно бути стрімке зростання бойової готовності та забезпечення управління загрозами і ризиками в умовах застосування прикордонних підрозділів швидкого реагування в регіональному збройному конфлікті під час службово-бойової діяльності [1].

Як свідчить майже трьохрічний досвід службово-бойової діяльності в умовах проведення антитерористичної операції (АТО), різке порушення нестійкої рівноваги природно-техногенних геосистем на Донбасі, пов'язане з застосуванням широкого спектру озброєнь та боєприпасів при наявності великої кількості потенційно-небезпечних об'єктів (ПНО). Це призвело до розвитку цілого ряду надзвичайних екологічних ситуацій, що викликані ураженням ПНО, де зберігаються сильнодіючі хімічні речовини, промислові відходи 1-3 класів небезпеки, радіаційних могильників i скотомогильників 3 небезпечними біологічними складники спор сибірки, вірусів туляремії, чуми та інших збудників небезпечних епідемічних захворювань. На ліквідацію таких НС не вистачає ні внутрішніх ресурсів, ні зовнішніх позик.

За таких умов єдине, що можна зробити, це запровадити чітку дієву систему екологічної безпеки в зоні проведення АТО, однією із важливих підсистем якої $\epsilon$ екологічний моніторинг прикордонних регіонів для попередження та прогнозування наслідків i оперативного реагування на НC.

Це дозволить зберегти не тільки здоров'я і дієздатність військовослужбовців Збройних Сил України, підрозділів ДПСУ та місцевого населення в зоні конфлікту, але й попередити розвиток транскордонних НС та оперативне реагування на них прикордонних підрозділів (ПП) в ході службово-бойової діяльності.

Відповідно до Положення про відділ прикордонної служби Державної прикордонної служби України, який затверджений Наказом Міністерства внутрішніх справ України № 311 від 15.04.2016, на нього покладаються завдання, пов'язані 3 аналізом цілого спектру мультисистемних загроз i ризиків у сфері прикордонної безпеки, що також стосуються моніторингу отруйних i радіоактивних речовин, небезпечних матеріалів та інших предметів, заборонених до переміщення через державний кордон України та до тимчасово окупованої території і 3 неї, охорони довкілля та збереження природних ресурсів, контролю за радіаційною 
обстановкою на ділянці відповідальності та заходи щодо реагування на надзвичайні ситуації техногенного та природного характеру, інформування органів державної влади та громадян про аварії, пожежі, катастрофи, стихійні лиха та інші надзвичайні події на державному кордоні України, у прикордонній смузі та контрольованих прикордонних районах у межах ділянки відповідальності, а також про дані та факти, що свідчать про загрозу безпеці суспільства і держави.

Аналіз останніх досліджень i публікацій. Проведення аналізу наукових публікацій щодо проблематики екологічного моніторингу прикордонних регіонів дозволило встановити, що на сьогодні в світі розроблено декілька його концепцій [2-5]. Під моніторингом навколишнього середовища розуміють “... стеження за станом оточуючого людину природного середовища i попередження про кризові ситуації, шкідливі для здоров'я людей та інших живих організмів" [3]. Відповідно до цього визначення головний зміст моніторингу полягає у здійсненні двох взаємопов'язаних функцій - спостереження (стеження) i попередження надзвичайних ситуацій природного або техногенного характеру. Це означає, що виконувані дії повинні мати характер рятівних робіт при ліквідації надзвичайних ситуацій (НC).

Подібну до вищевикладеної концепції запропонував Б. В. Виноградов у своїй монографії [4]. Як об'єкт моніторингу розглядають екосистеми, основний метод аерокосмічний. Питання щодо управління, регулювання, нормування екологічної безпеки та оптимізації іiі рівня в цій концепції не визначаються.

У сімдесятих роках в Радянському Союзі було розроблено дві альтернативні концепції екологічного моніторингу. Автором однієї 3 них був Ю. А. Ізраель. Сильною стороною цієї концепції була спрямованість на фіксацію антропогенних змін природного середовища [5]. Однак, аналіз цієї концепції свідчить, що ефективність ненаціленого на управління екологічного моніторингу низька.

Автор іншої концепції І. П. Герасимов розумів під моніторингом “систему спостереження, контролю і керування станом довкілля, яка здійснюється у різних масштабах..." [6]. Велика роль в цій концепції відводиться науці: “... спостереження, контроль і керування станом навколишнього середовища повинні бути цілеспрямовані, взаємопов'язані та ефективні (повноцінні)". Ним була запропонована триступенева ієрархія моніторингу: 1-й ступінь - біоекологічний (санітарно-гігієнічний) моніторинг; 2-й ступінь - геоекологічний моніторинг (природногосподарський), який включає спостереження за станом природних екосистем i перетворенням їх у природно-техногенні; 3-й ступінь - біосферний моніторинг (глобальний).

Проведений аналіз існуючих концепцій 3 точки зору їх застосування для створення системи прикордонного екологічного моніторингу та актуальних публікацій [7-9] потребує детальної проробки концептуальних питань щодо його суті, структури, видів, особливостей реалізації та передумов створення системи прикордонного екологічного моніторингу в умовах збройного конфлікту в Україні.

В зв'язку з цим, в нинішніх умовах, що склалися на ділянці Східного та Південного регіонального управління, при веденні Російською Федерацією гібридної війни проти нашої країни в умовах реалізації загроз радіаційного, хімічного та бактеріологічного характеру для особового складу ДПСУ та місцевого населення, що проживає на цих та прилеглих до них територіях, зростає ймовірність ураження потенційно небезпечних об'єктів звичайними боєприпасами [10], що може призвести до виникнення масштабних $\mathrm{HC}$.

Таким чином, для прийняття відповідних управлінських рішень та забезпечення екологічної безпеки за умов, коли ДПС України здійснює покладені на неї завдання 3 охорони та захисту кордонів нашої Батьківщини, виникає актуальне наукове завдання розробки концепції екологічного моніторингу при ведені службово-бойової діяльності прикордонних підрозділів на ділянці регіонального управління.

Мета статті - наукове обгрунтування принципів і підходів до розробки концепції екологічного моніторингу при ведені службово-бойової діяльності прикордонних підрозділів на ділянці Східного регіонального управління 3 можливістю застосування функції управління екологічним станом довкілля.

Виклад основного матеріалу. При організації спостережень за станом навколишнього природного середовища (НПС) в операційних зонах i районах ведення службово-бойової діяльності (СБД) прикордонних підрозділів принципове значення має виділення природних та техногенних процесів із різними просторово- 
часовими частотами, що відображають масштаби та глибину перетворень в екосистемах прикордонного регіону. Згідно 3 цим, екологічний моніторинг можна розділити на наступні ієрархічні рівні:

регіональний моніторинг в зоні військового конфлікту на Сході України;

локальний моніторинг операційних $30 \mathrm{H}$ та районів ведення СБД прикордонних підрозділів;

об'єктовий (імпактний) моніторинг (здійснюється 3 урахуванням специфіки військових об'єктів чи потенційно небезпечних об'єктів в районі ведення СБД прикордонних підрозділів).

Екологічний моніторинг операційних зон і районів ведення СБД прикордонних підрозділів (ПП) у загальній ієрархічній структурі відноситься до локального та об'єктового моніторингів і $є$ комплексною системою, тому що включає спостереження, оцінку й прогнозування змін стану абіотичної складової екосистем під впливом небезпечних факторів i забруднень як військового так i промислового походження та довгостроковим незадовільним землекористуванням в цьому промисловому регіоні України і відповідної їх реакції на ці зміни. Необхідною умовою успішного функціонування такого моніторингу є оцінка і прогнозування впливу чинників воєнно-техногенного навантаження (ВТН), можливості ураження промислових ПНО та могильників і об'єктів критичної інфраструктури внаслідок ведення бойових дій (БД), а також розробкою заходів 3 управління екологічною безпекою прикордонного регіону.

Для локальних районів ведення СБД, де розташовані ПНО та об'єкти прикордонної інфраструктури, повинні бути розгорнуті безпровідні сенсорні мережі об'єктового моніторингу, при організації яких слід враховувати значну мінливість чинників ВТН. Ця мінливість визначається характеристиками джерел забруднення та ВТН, метеорологічними умовами, ландшафтними особливостями місцевості, станом водних об'єктів і підстиляючої поверхні, а також геологічними процесами верхньої зони геологічного середовища (підтоплення, карст, зсуви, ерозія, просідання і т. ін.).

Вирішення цих задач на державному рівні поки що успішно здійснюється тільки там, де створені стаціонарні i рухомі пункти контролю: на атомних та теплових електростанціях, у районах розташування військових та промислових об'єктів підвищеного ризику (арсенали, бази, склади, військові полігони, гірничо-видобувна, хімічна та металургійна промисловість), на великих промислових комбінатах, у місцях забору води для централізованого водопостачання.

На сьогодні на більшості цивільних об'єктів і об'єктах прикордонної інфраструктури практично неможливо організувати систему довгострокових регулярних спостережень за станом НПС у зв'язку зі значною трудомісткістю та значними фінансовими витратами на одержання вхідних даних моніторингу і методів їхньої обробки, що потребує спеціалізованого лабораторного обладнання з залученням висококваліфікованих фахівців.

Концепція екологічного моніторингу при ведені службово-бойової діяльності прикордонних підрозділів на ділянці Східного регіонального управління будується на ряді основоположних принципів моніторингу довкілля, які обумовлені характером функціональних задач, а також його місцем в системі екологічної безпеки під час ведення СБД ПП. Дерево основних принципів такого екологічного моніторингу наведено на рис. 1.

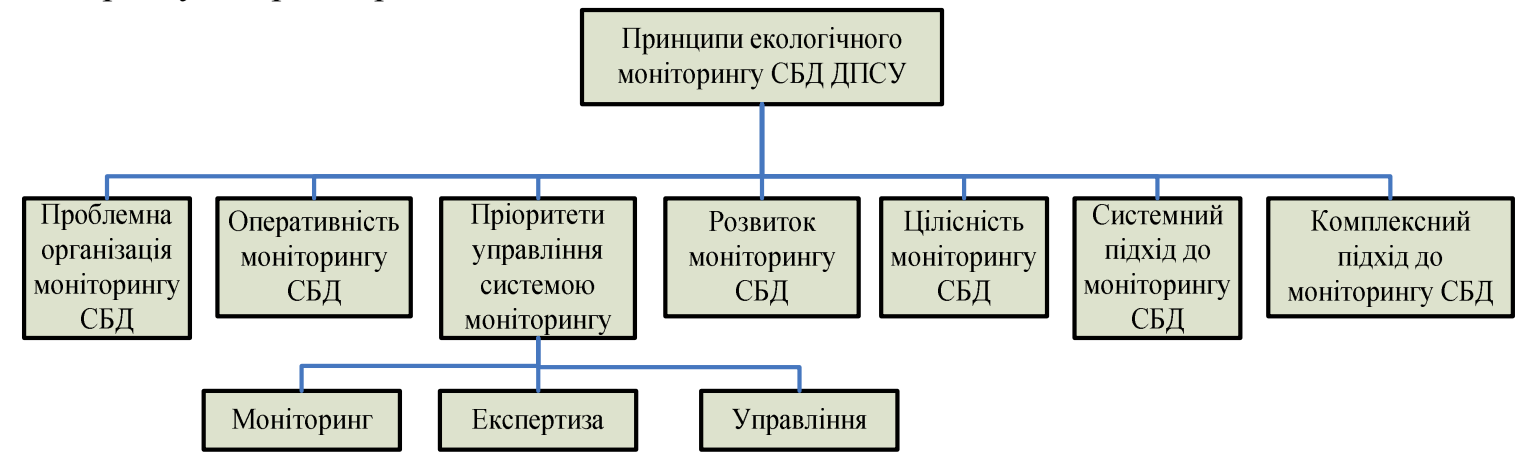

Рис. 1. Принципи екологічного моніторингу СБД ПП

\begin{abstract}
Важливим принципом екологічного моніторингу $є$ принцип проблемної тотального моніторингу [7] і знімає синдром

“надлишку даних - браку інформації” [6].
\end{abstract} організації. Цей принцип протилежний до ідеї 
Програма дослідження і спостереження розгортається тільки під певну екологічну проблему при веденні СБД ПП. При вирішенні цієї проблеми програма моніторингу згортається, інтенсивність спостережень знижується, а за певними показниками вони припиняються. Моніторинг ведення СБД ПП на рівні Східного регіонального управління може складатися 3 пакета таких проблемно організованих програм:

- стан забруднення основних і резервних джерел питно-господарського водопостачання ПП;

- стан забруднення грунтів в пунктах базування ПП;

- стан забруднення грунтових вод в пунктах базування ПП;

- стан забруднення поверхневих вод в пунктах базування ПП;

- стан забруднення приземного шару повітря в операційних зонах і районах ведення СБД;

- стан порушення природних ландшафтів в операційних зонах і районах ведення СБД;

- стан забруднення НПС важкими металами в пунктах базування ПП;

- стан радіаційного фону в операційних зонах і районах ведення СБД;

- стан забруднення складових НПС радіонуклідами в операційних зонах і районах ведення СБД;

- стан забруднення НПС збідненим ураном в операційних зонах і районах ведення СБД.

Проблемний принцип організації постійно залишає можливість для постановки нових проблем і розгортання нових програм моніторингу під час ведення СБД ПП, $\mathrm{i}$, отже, система залишається відкритою для розвитку. Це другий принцип організації екологічного моніторингу під час ведення СБД ПП.

Принцип пріоритету управління (організаційної ієрархії) виник як антитеза середовищному підходу i відповідно екологічному моніторингу, побудованому на середовищному підході як ненаціленому на вирішення екологічних проблем в зоні військового конфлікту. У тріаді управліннямоніторинг-експертиза управлінню належить провідна роль, моніторинг та експертиза $\epsilon$ дуже важливими, але тільки блоками забезпечення. У блоці “управління" розробляють цільові установки і намічають контур екологічної проблеми, під яку буде будуватися моніторинг СБД ПП. Екологічна експертиза використовується як засіб проти можливої професійної вузькості вирішення проблеми. Одним із результатів екологічного моніторингу $\epsilon$ цільова інформація, що призначена для підтримки прийняття управлінського рішення. У нерозривності цієї тріади і полягає інший принцип - цілісності.

Оперативність екологічного моніторингу СБД ПП повинна виражатися не стільки у технічній стороні справи - оперативності збору, обробки і передачі інформації, - скільки в оперативності прийняття рішень у критичних ситуаціях при веденні СБД ПП. За такої вимоги екологічна інформація, що надається командиру ПП, повинна бути орієнтована на прийняття командирського рішення і містити, наприклад, типи та можливі сценарії розвитку екологічних ситуацій і дії щодо їх розв'язання під час СБД ПП.

Організація комплексного екологічного моніторингу під час СБД ПП спирається на принцип системного підходу до аналізу результатів спостережень, оцінок і прогнозів, що здійснюються у відношенні складових військової природно-техногенної геосистеми (ВПТГС). Для оцінки впливу ВТН необхідно обгрунтувати комплекс показників, який би забезпечив функціонально повну характеристику вектору екологічного стану (ВЕС) ВПТГС [10].

Через те, що екологічним моніторингом передбачається поєднання спостережень за абіотичною складовою екосистеми, оцінювання i прогнозування відповідних реакцій іiі біотичної складової, в організацію і здійснення екологічного моніторингу операційних зон i районів ведення СБД закладається принцип комплексності моніторингу - гармонійне поєднання геологічного (геофізичного), біологічного та моніторингу джерел і факторів BTH.

$\begin{array}{ccc}\text { Геологічний моніторинг } & \text { включає } \\ \text { елементи спостереження, } & \text { оцінки, }\end{array}$ прогнозування стану i змін геофізичного середовища (сукупності фізичних, фізикохімічних і хімічних процесів та властивостей визначених ділянок ВПТГС), тобто змін абіотичної (геологічної) складової екосистеми як у мікро-, так і в макромасштабі, включаючи забруднення навколишнього середовища різними інгредієнтами воєнно-техногенного походження. Його результат можна визначити у вигляді вектору стану абіотичного середовища

$$
\text { Abio }=\left(A, S, W^{s}, W^{g}\right),
$$

де $A$ - індикатор стану атмосферного повітря; $S$ - індикатор стану грунту; $W^{s}$ - індикатор 
стану поверхневих вод; $W^{g}-$ індикатор стану грунтових вод.

Основною задачею біологічного моніторингу $\epsilon$ визначення ВЕС біотичної складової екосистеми, функції його відгуку (реакціï) на воєнно-техногенний вплив, визначення відхилення його від гомеостазу на різних рівнях організації біосфери (рівні організмів, популяційному, екосистеми та ландшафту). При організації i здійсненні біологічного моніторингу передбачається також спостереження, оцінка і прогноз стану здоров'я людини та найважливіших популяцій природних видів як 3 погляду стійкого існування військової екосистеми, так і їх господарської цінності (наприклад, мисливських тварин та цінних видів промислових риб). Крім того, ведеться спостереження й оцінюється стан найбільш чутливих до того чи іншого ВТН популяцій рослин i тварин. Його результат можна визначити у вигляді вектору стану біотичного середовища

Bio $=($ Fito, Zoo, Mico, Microbo, Human $)$, (2) де Fito - індикатор стану фітоценозу; Zoo індикатор стану зооценозу; Mico - індикатор стану мікоценозу; Microbo - індикатор стану мікробоценозу; Human - індикатор стану здоров'я людини.
До функціональних задач екологічного моніторингу операційних зон і районів ведення СБД ПП повинен входити також моніторинг джерел i факторів ВТН. Цей моніторинг повинен включати виявлення пошкоджень рослинного та грунтового покриву й ураження складових ВПТГС факторами ВТН та контроль за їх поширенням. Його результат можна визначити у вигляді вектору стану ВТН

$$
M T L=\left(m t l_{\text {мex }}, m t l_{\text {xim }}, m t l_{\phi i 3}\right),
$$

де $m t l_{\text {мех }}$ - індикатор механічного ВТН; $m t l_{\text {хім }}$ - індикатор хімічного ВТН; $m t l_{\phi i з}-$ індикатор фізичного ВТН.

У цьому випадку, запропонований принцип екологічного моніторингу операційних зон і районів ведення СБД ПП, організований і здійснюваний як триєдиний геологічний, біологічний та моніторинг джерел i факторів ВТН, обгрунтовано може бути названий системним.

Якщо провести декомпозицію системи екологічного моніторингу (СЕМ) СБД ПП за компонентами спостереження, що спрямоване на відтворення об'єктивної картини екологічного стану ВПТГС та ВТН, то їх систему можна представити у вигляді ієрархічного дерева (рис. 2).

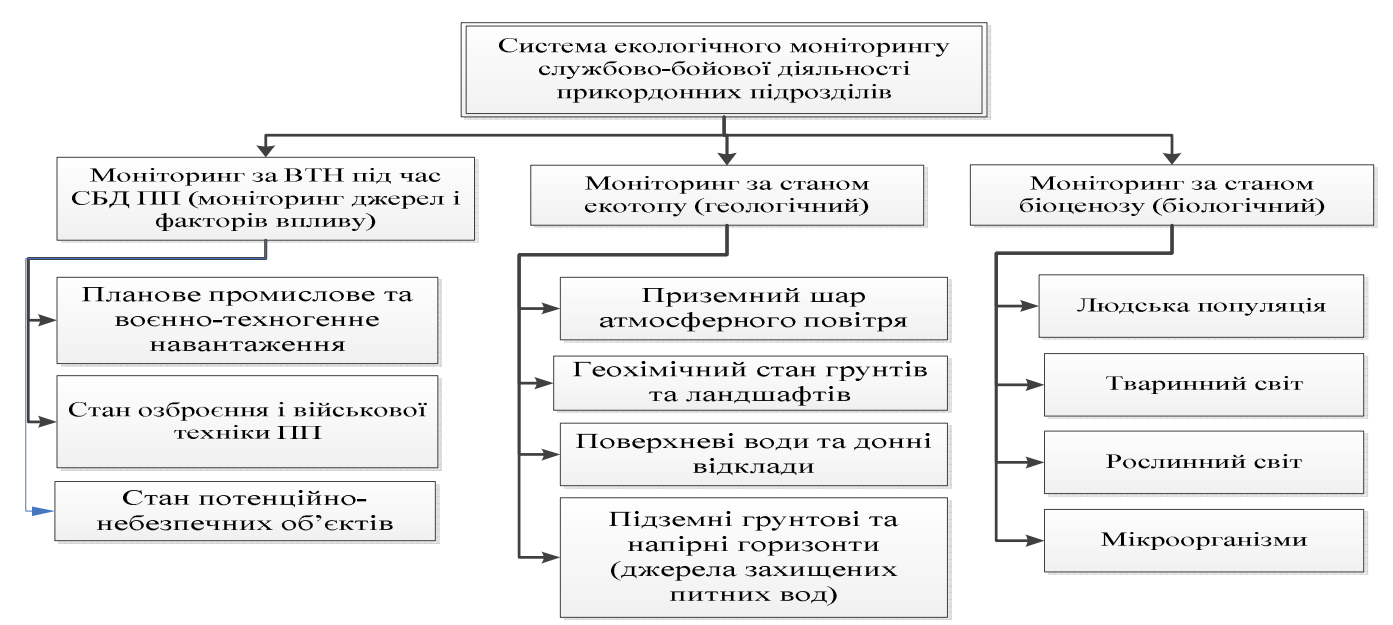

Рис. 2. Дерево системного екологічного моніторингу СБД ПП

Наступною ознакою системної організації i здійснення екологічного моніторингу операційних зон i районів ведення СБД ПП $є$ поєднання i збалансованість вирішення його системних задач, пов'язаних 3 постійним спостереженням, оцінкою і прогнозуванням стану ВПТГС та задач моніторингу, що витікають 3 характеру і змісту часткових екологічних проблем глобального, регіонального чи місцевого масштабу.
Системний i комплексний характер екологічного моніторингу також визначається застосуванням методів системного аналізу показників, які характеризують вплив факторів ВТН на різні складові НПС та стан екосистем операційних зон і районів ведення СБД ПП.

У процесі екологічного моніторингу операційних зон і районів ведення СБД ПП організовуються i здійснюються спостереження, оцінка i прогнозування як природних змін ВПТГС, так і змін, викликаних 
воєнно-техногенним навантаженням, які накладаються на природні зміни.

Розглянутий системний принцип організації і здійснення екологічного моніторингу операційних зон i районів ведення СБД ПП передбачає виділення пріоритетних показників для контролю стану приземного шару повітря, літосфери, природних біоценозів, поверхневих та грунтових вод, а також стану здоров'я особового складу ДПСУ i людей в районі проведення СБД ПП.

Про деякі пріоритетні показники для контролю стану атмосферного повітря в зонах високих воєнно-техногенних навантажень можна сказати наступне. Відповідно до рекомендацій Всесвітньої організації охорони здоров'я і досвіду Європейської екологічної комісії, до числа шкідливих речовин, які містяться в атмосфері i повинні контролюватися, в першу чергу, відносяться: діоксид сірки, оксиди азоту, оксид вуглецю, озон, пил, вуглеводні, у тому числі бенз(а)пирен і діоксин [11]. Існує пріоритетний перелік хімічних речовин, що містяться в повітрі і підлягають контролю [12]. Вiн повинен враховуватися при організації моніторингу.

Забруднення поверхневих вод, у тому числі річок, озер та інших водойм, обумовлюється, головним чином, можливими поверхневими стоками 3 територій інтенсивного ВТН операційних зон і районів ведення СБД ПП, а також господарськопобутовими (комунальними) стоками військових містечок і сільськогосподарськими стоками 3 розораних земель та підсобних господарств. Найбільш розповсюдженими забруднюючими речовинами в поверхневих водах $\epsilon$ нафтопродукти, феноли, органічні речовини, сполуки міді, цинку, а в окремих регіонах амонійний i нітратний азот, формальдегід і т. ін. [13].

При організації екологічного моніторингу операційних зон і районів ведення СБД ПП в число пріоритетних забруднювачів поверхневих вод, на наш погляд, необхідно включити, насамперед, ті 3 них, за якими систематично перевищуються граничнодопустимі концентрації (ГДК), що встановлені санітарними i рибоохоронними правилами. У перелік такого роду речовин, для яких за статистикою відзначається перевищення ГДК у воді, варто включити: нафтопродукти, сполуки органічних речовин, феноли, аніонні поверхнево-активні речовини, амонійний азот, сполуки міді, цинку, ртуті, в окремих регіонах - кобальту, міді, урану [13, 14].

Для моніторингу поверхневих вод існують пріоритетні проблеми, які доцільно враховувати при його організації і здійснені. Комплексне і багатокомпонентне забруднення поверхневих вод не може бути оцінене за сумою окремих санітарно-гігієнічних показників (ГДС, ГДК, ТН і т. ін.), тому зараз почали широко використовувати біотестування як метод інтегральної оцінки поведінки складних біосистем при комплексній дії фізичних, фізико-хімічних, хімічних та інших чинників техногенезу [15].

До числа пріоритетних видів контролю літосфери операційних зон і районів ведення СБД ПП варто віднести контроль стану забруднення грунтів і грунтових вод, донних відкладів поверхневих водних об'єктів, розвиток ерозійних і дефляційних процесів у техногенно навантажених зонах території операційних зон і районів ведення СБД ПП.

В якості об'єктів моніторингу грунтів слід використовувати такі [16]:

основні типи, підтипи, роди, види та різновидності грунтів в межах однієї грунтової провінції. Вони повинні відображати строкатість грунтового покриття даної провінції та всі різновиди і рівні антропогенних навантажень;

природні об'єкти, на які не вплинула антропогенна діяльність (лісові та степові заповідники);

еталонні об'єкти на грунтах iз сільськогосподарським їх використанням в умовах високої культури землеробства: поля держсортодільниць; поля господарств, де впроваджено контурно-меліоративну організацію території або систему грунтозахисного чи органічного землеробства; поля, які розміщені поруч вказаних еталонних об'єктів;

параметри клімату - опади та їх розподіл впродовж року; температура повітря; кількість днів із сильними вітрами; середня швидкість вітру під час пилових бур та їх тривалість протягом року;

грунтотворні породи - їх стан та рівень забруднення, що впливає на ступінь забруднення в цілому всього грунту;

грунтові та підземні води - їх стан відображає спрямованість та інтенсивність грунтотворних процесів, що відбуваються при формуванні грунту;

кількість та якість продукції рослинництва - оскільки це відображає рівень 
родючості грунтів, ступінь їх деградації чи забруднення.

Для моніторингу біотичної складової ВПТГС в цілому при спостереженні, оцінці і прогнозуванні іi стану пріоритетна роль належить визначенню й аналізу різного роду інтегральних показників, зокрема, інтегральної характеристики стану біоценозів, що включає водні i наземні організми (визначається методами біоіндикації), загальної характеристики стану здоров'я особового складу та населення, що проживає на прилеглих територіях. За аналогією до норм радіаційної безпеки НРБУ-97, слід провести градацію впливу ВТН на людей за 2 категоріями:

категорія А (працівники та особовий склад ПП ДПСУ) - особи, які постійно чи тимчасово безпосередньо взаємодіють 3 джерелами воєнно-техногенного навантаження;

категорія В - все населення, яке проживає на території операційних зон i районів ведення СБД ПП та на прилеглих територіях (розрахункові зони екологічного впливу ВТН).

Були також перераховані види вимірів програм моніторингу, які варто проводити, коли забруднювач сам по собі важко вимірюється (непрямий моніторинг). Для цього потрібен вимір наступних величин:

індикаторів якості води (колі-бактерії, БПК5, ХПК, синьо-зелені водорості, їхня первинна продуктивність);

індикаторів якості грунту (солоність, відношення кислотності i лужності, вміст нітритів і органічного азоту, вміст гумусу);

індикаторів здоров'я людини і тварин, індикаторів ураження рослин (випадки захворювань, генетичні наслідки, чутливість до ліків);

рослинних індикаторів забруднень.

Пріоритети для моніторингу природних біоценозів істотно залежать від типу ландшафтів, характеру та ступеня їх білегеративної трансформованості і специфіки військових об'єктів. Принцип ієрархічності в організації та здійсненні екологічного моніторингу операційних зон і районів ведення СБД ПП полягає в тому, що всі його основні елементи узгоджуються й закладаються у визначену ієрархічну структуру:

регіональний;

локальний (імпактний) чи об' єктовий.

Імпактний екологічний моніторинг організовується і здійснюється на рівні окремих частин ДПСУ та операційних зон i районів ведення СБД ПП як самостійних військових природно-техногенних геосистем “воєнно-техногенний об'єкт - довкілля”.

Поле дії цієї структурної ланки комплексного екологічного моніторингу операційних зон і районів ведення СБД ПП повинно охоплювати визначену сукупність біосферних i воєнно-техногенних об'єктів, безпосередньо пов'язаних між собою процесами взаємодії. У цьому випадку може предметно контролюватись й оцінюватись вплив ВТН, в першу чергу, на об'єкти біосфери i, в тому числі, людину, а також можуть прийматися адекватні заходи для нормалізації екологічної обстановки. За сучасними уявленнями, саме на місцевому рівні за даними імпактного моніторингу повинно здійснюватися оперативне екологічне управління станом ВПТГС [16].

Крім розглянутих вище, при організації і здійсненні екологічного моніторингу операційних зон і районів ведення СБД ПП реалізується ще ряд принципів:

принцип системного підходу у вивченні взаємодії між складовими ВПТГС і шляхами біогеохімічного круговороту речовин;

принцип організації i здійснення екологічного моніторингу операційних зон i районів ведення СБД ПП за екосистемними процесами, коли при спостереженні, оцінюванні і прогнозуванні стану екосистем визначаються їхні ключові параметри (чутливі до відповідних змін і природних рівнів мінливості, які дозволяють статистично визначити відхилення від норми).

Для забезпечення стабільного управління екологічною безпекою в операційних зонах та районах ведення СБД ПП розроблено структурно-логічну модель екологічного моніторингу при різних умовах застосування ДПС України із забезпеченням мінімальних ризиків та загроз виникнення надзвичайних ситуацій природного та техногенного характеру в цьому регіоні.

Структурно-функціональна модель екологічного моніторингу в операційних зонах та районах ведення СБД ПП наведена на рис. 4.

Висновки. Структурно-функціональна модель системи екологічного моніторингу ведення СБД ПП являє собою сукупність конкретних методів, форм, прийомів, інструментів і важелів регулювання екологічної безпеки, через удосконалення яких, власне кажучи, здійснюється удосконалення системи забезпечення екологічної безпеки ПП ДПСУ на ділянці Східного регіонального управління. 
Напрям подальших досліджень. Для подальшого розвитку цієї системи в статті запропоновано застосувати визначені принципи, які створюють передумови для розробки ефективних процедур управління екологічною безпекою ДПС України в умовах НС природного, техногенного та воєннотехногенного походження.
Для оцінки ефективності механізмів екологічного моніторингу та державного регулювання екологічної безпеки на рівні Східного регіонального управління пропонується застосувати методи аналізу ієрархій та аналітичних мереж.

Індикатори (індекси) воєнно-техногенного навантаження

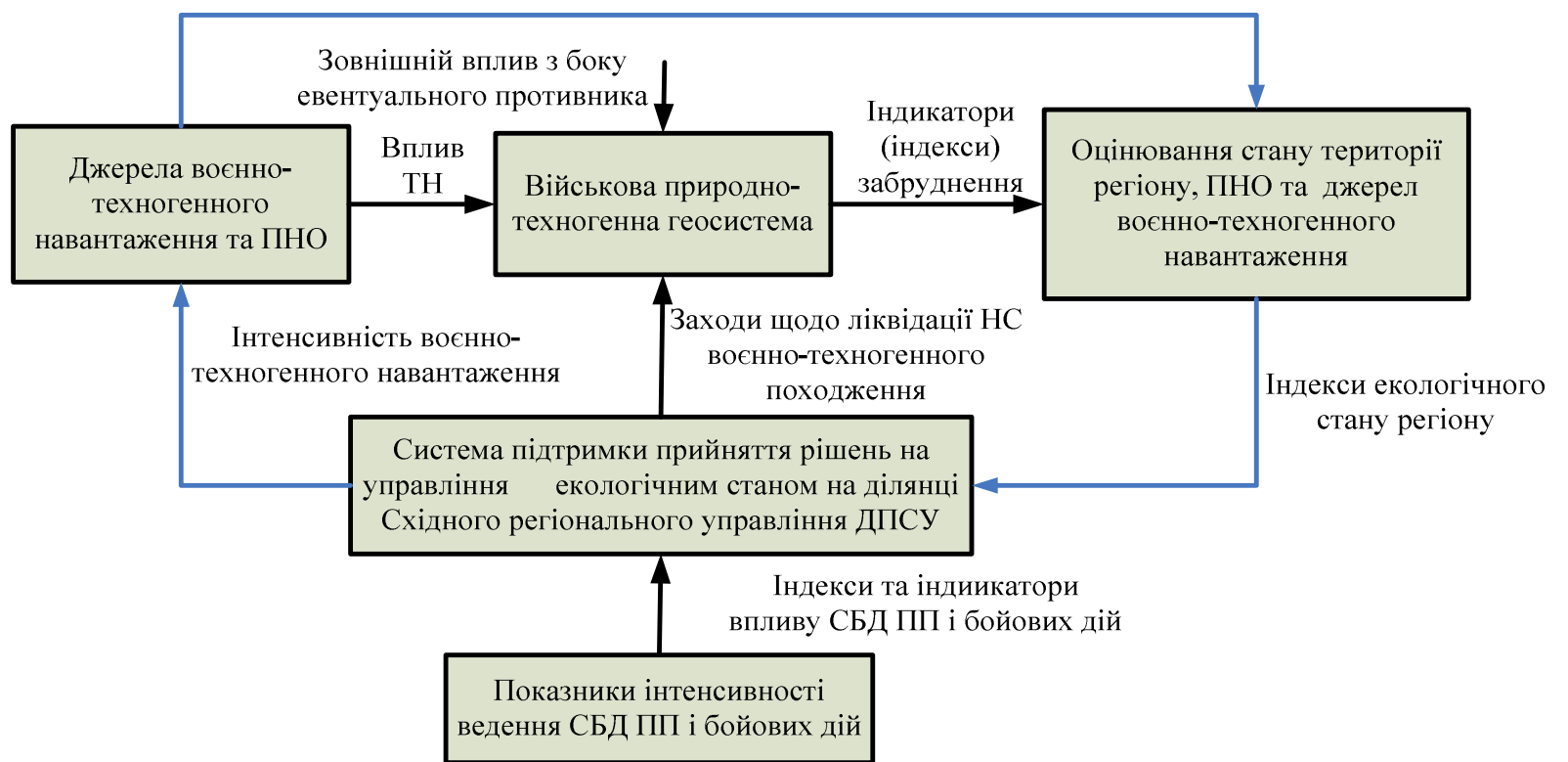

\section{Рис. 3. Структурно-функціональна модель системи екологічного моніторингу ведення СБД ПП}

\section{СПИСОК ВИКОРИСТАНОЇ ЛІТЕРАТУРИ}

1. Заява Президента України за результатами зустрічі з Віце-Президентом США 16 січня 2017 року [Електронний ресурс] - Режим доступу: http://www. president.gov.ua/ news/ zayavaprezidenta-ukrayini-za-rezultatami-zustrichi-z-vicep-39490

2. Положення про відділ прикордонної служби Державної прикордонної служби України. Наказ Міністерства внутрішніх справ України № 311 від 15.04.2016. - [Електронний ресурс] - режим доступу http: //zakon3.rada.gov.ua/ laws/ show/ z0719-16

3. Реймерс Н. Ф. Природопользование. - М.: Мысль. 1990. - 637 с.

4. Виноградов Б. В. Аэрокосмический мониторинг экосистем. - . - М.: Наука. 1984. - 320 с.

5. Израэль Ю. А. Глобальная система наблюдений. Прогноз и оценка окружающей природной среды. Основы мониторинга // Метеорология и гидрология. - 1974. - №7. - С. 3-8.

6. Израэль Ю. А. Экология и контроль состояния природной среды. - Л., 1979.

7. Герасимов И. П. Научные основы современного мониторинга окружающей среды // Изв. АН СССР. Сер географ. - 1975. - № 3. - С. 13- 25.

8. Погребенник В. Екологічний моніторинг: концепції, принципи, системи / В. Погребенник, Н. Мельник, М. Бойчук // Вимірювальна техніка та метрологія. - Вип. 65, 2005. - С. 164 - 171.
9. Пилипович O. Організація прикордонного екологічного контролю: навч.-метод.посібник / Ольга Пилипович. - Львів : ЛНУ імені Івана Франка, 2012. - 208 с.

10. Данилюк, С. Л. Підвищення продуктивності мобільних радіомереж на основі БПЛА для завдань екологічного моніторингу в зоні ведення бойових дій [Текст] / С. Л. Данилюк // Системи озброєння і військова техніка. - Х.: ХУПС, 2015. №3 (43). - С. 76-80.

11. Жирохов, М. Де пролягає “червона лінія” для Донбасу - [Електронний ресурс] - режим доступу http://www.depo.ua/ukr/politics/de-prolyagaechervona-liniya-dlya-donbasu-03072016180500

12. Лисенко О. I. Напрямки вдосконалення природоохоронної діяльності в Збройних Силах України: Науково-методичний посібник / Під ред. О. І. Лисенка, С. М. Чумаченка, Ю. І. Ситника. К.: ННДЦ ОТ і ВБ України, 2006. — 424 с.

13. Махкамов М. М. Охорона природного середовища у Збройних Силах України: Посібник / Під ред. В. М. Литвака. - К.: Варта, 1998. - 208 с.

14. Артем'єв С. Р., Блекот О. М., Марущенко В. В., Чумаченко С. М.. Блажаєвський М. С. Екологічна безпека військ.: Підручник 3 грифом МОНУ. Харків: НТУ «ХПІ», 2012. - 308 с.

15. Романченко I. С., Сбітнєв А. І., Бутенко С. Г. Екологічне забезпечення військ: Монографія. - К. НАО України, 2003. - 274 с. 
16. Экоинформатика. Теория. Практика. Методы и системы / Под ред. академика РАН В. Е. Соколова. - СПб.: Гидрометеоиздат, 1992. $520 \mathrm{c}$.

17. Экологическая безопасность. Общие принципы и российский аспект : учеб. пособие /
В. И. Данилов-Данильян,

М. Ч. Залиханов, К. С. Лосев. - Изд. 2-е, дораб. - М. : МППАБИМПА, 2007. - С. 288.

18. Шевчук В. Я., Саталкін Ю. М., Білявській Г. О. та ін.. Екологічне управління. - К.: Либідь, 2004. 429 c.

Стаття надійшла до редакції 13.06.2017

Ткачук П. $\mathbf{C}^{1}$;

Ворона T. A. ${ }^{2}$

1 - Национальная академия Государственной пограничной службы Украины имени Богдана Хмельницкого, Хмельницкий;

2 - Центр военно-стратегических исследований Национального университета обороны Украины имени Ивана Черняховского, Киев

Подходы к созданию концепции экологического мониторинга операционных зон регионального вооруженного конфликта при ведении служебно-боевой деятельности пограничных подразделений на участке регионального управления

Резюме. В статьи приведены основные подходы для построения концепции экологического мониторинга при ведении служебно-боевой деятельности пограничных подразделов на участке регионального управления с точки зрения формирования его функциональной схемы и составных элементов для оценки изменений состояния пограничных природно-техногенных геосистем.

Ключевые слова: экологический мониторинг, концепция, природно-техногенная геосистема, военно- техногенная нагрузка, вооруженный конфликт, окружающая среда, пограничные районы, служебно-боевая деятельность, пограничное подразделение, индикаторы, региональное управление.

\section{P. Tkachuk ${ }^{1}$;}

T. Vorona ${ }^{2}$

${ }^{1}$ - National Academy of the State Border Service of Ukraine named after Bohdan Khmelnytsky, Khmelnytsky;

${ }^{2}$ - Center for Military and Strategic Studies of the National Defence University of Ukraine named after Ivan Chernyhovsky, Kyiv

Concerning the construction of the concept of environmental monitoring of the operational zones of the regional armed conflict in the conduct of the military-operational activities of the border divisions at the regional administration section

Resume. The article presents the main approaches for constructing the concept of environmental monitoring in the conduct of the service and combat activities of border divisions at the regional administration from the point of view of the formation of its functional scheme and components for assessing the changes in the state of the border natural-ethnogeny geosystems.

Keywords: ecological monitoring, concept, natural and ethnogeny geosystem, military-man-made load, armed conflict, environment, border areas, combat service, border guard, indicators, regional administration 